\title{
Methodiek werkgelegenheid en scholing 1997
}

Citation for published version (APA):

Welters, R. A. M. H. M., Smits, W., de Grip, A., Sanders, J. M. A. F., van Loo, J. B., \& de Steur, M. J. (1998). Methodiek werkgelegenheid en scholing 1997. Researchcentrum voor Onderwijs en Arbeidsmarkt, Faculteit der Economische Wetenschappen. ROA Working Papers No. 2

https://doi.org/10.26481/umarow.1998002

Document status and date:

Published: 01/01/1998

DOI:

10.26481/umarow.1998002

Document Version:

Publisher's PDF, also known as Version of record

\section{Please check the document version of this publication:}

- A submitted manuscript is the version of the article upon submission and before peer-review. There can be important differences between the submitted version and the official published version of record.

People interested in the research are advised to contact the author for the final version of the publication, or visit the DOI to the publisher's website.

- The final author version and the galley proof are versions of the publication after peer review.

- The final published version features the final layout of the paper including the volume, issue and page numbers.

Link to publication

\footnotetext{
General rights rights.

- You may freely distribute the URL identifying the publication in the public portal. please follow below link for the End User Agreement:

www.umlib.nl/taverne-license

Take down policy

If you believe that this document breaches copyright please contact us at:

repository@maastrichtuniversity.nl

providing details and we will investigate your claim.
}

Copyright and moral rights for the publications made accessible in the public portal are retained by the authors and/or other copyright owners and it is a condition of accessing publications that users recognise and abide by the legal requirements associated with these

- Users may download and print one copy of any publication from the public portal for the purpose of private study or research.

- You may not further distribute the material or use it for any profit-making activity or commercial gain

If the publication is distributed under the terms of Article $25 \mathrm{fa}$ of the Dutch Copyright Act, indicated by the "Taverne" license above, 


\title{
Methodiek werkgelegenheid en scholing 1997
}

\author{
ROA-W-1998/2
}

Andries de Grip, Jasper van Loo, Jos Sanders,

Wendy Smits, Margot de Steur, Riccardo Welters

Researchcentrum voor Onderwijs en Arbeidsmarkt

Faculteit der Economische Wetenschappen en Bedrijfskunde

Universiteit Maastricht

Maastricht, december 1998 
ISBN 90-5321-236-1

SEC98.030/JVL

Inhoud 
Bladzijde

Voorwoord

1 Inleiding 1

2 Databronnen 2

3 Definities en indices $\quad 5$

4 Typeringen en trends $\quad 12$

5 Analyses $\quad 14$

5.1 Fysieke belasting $\quad 15$

5.2 De kans op arbeidsongeschiktheid 15

5.3 Technologische en organisatorische ontwikkelingen per bedrijfssector en -grootte 16

$\begin{array}{ll}5.4 \text { Employability van de werkenden } & 17\end{array}$

$\begin{array}{ll}5.5 \text { Perspectiefrijke scholingstrajecten } & 18\end{array}$

6 Besluit 20

$\begin{array}{ll}\text { Literatuur } & 21\end{array}$ 


\section{Voorwoord}

In dit werkdocument wordt een overzicht gegeven van de onderliggende methodiek die in 1997 is gehanteerd bij de totstandkoming van de diverse indicatoren en de specifieke analyses ten behoeve van het Werkgelegenheid en Scholing Observatorium (WSO). De onderzoeksresultaten zijn gepubliceerd in Werkgelegenheid en scholing 1997 en de bijbehorende Statistische bijlage.

Het onderzoek is verricht in opdracht van het Ministerie van Sociale Zaken en Werkgelegenheid, in het kader van de stimuleringsprogramma's ESF-4 Scholing voor behoud van werk en ADAPT. De projectleiding van het onderzoek was in handen van dr. A. de Grip. Verder is aan het onderzoek meegewerkt door drs. J.B. van Loo, J.M.A.F. Sanders, H. Schonk, drs. W. Smits, drs. M. van Smoorenburg, drs. M.J. de Steur en drs. R.A.M.H.M Welters. 


\section{Inleiding}

In het kader van de stimuleringsprogramma's ESF-4 Scholing voor behoud van werk en $A D A P T$ van de Europese Commissie heeft het Ministerie van Sociale Zaken en Werkgelegenheid eind 1995 het Researchcentrum voor Onderwijs en Arbeidsmarkt de opdracht gegeven een waarnemingspost in te stellen. Het rapport Werkgelegenheid en scholing 1997 en de bijbehorende Statistische bijlage vormen tezamen de tweede overzichtsrapportage van dit Werkgelegenheid en Scholing Observatorium (WSO). In deze beide publicaties is geprobeerd de resultaten van het verrichte onderzoek op een toegankelijke wijze te presenteren. De gehanteerde methodiek komt in dit werkdocument aan de orde.

Het WSO kent de volgende opzet. Allereerst wordt onderzocht welke groepen werkenden als gevolg van kwalificatieveroudering een risico op verlies van werk lopen. Deze kwalificatieveroudering kan verschillende oorzaken hebben. Allereerst kan er kwalificatieveroudering plaatsvinden als gevolg van fysiek of psychisch belastende arbeidsomstandigheden. Deze kwalificatie-veroudering doet zich voor als werkenden vanwege deze belastende arbeidsomstandigheden niet langer in staat zijn hun huidige werk uit te oefenen. Daarnaast kan er sprake zijn van kwalificatieveroudering door snelle technologische en organisatorische ontwikkelingen. Een krimpende werkgelegenheid of verschuivingen in de werkgelegenheid (reallocatie) binnen bedrijfssectoren, beroepen of opleidingen kan een derde oorzaak van kwalificatieveroudering zijn. Het WSO traceert de groepen werkenden die met één of meerdere risico's op kwalificatieveroudering worden geconfronteerd. Indien deze risicogroepen onvoldoende her-, om- of bijscholing volgen of de employability van de werkenden tekortschiet, kunnen extra scholingsactiviteiten wellicht werkgelegenheidsproblemen voorkomen. Het moet dan gaan om scholingsactiviteiten die deze werkenden betere kansen op de arbeidsmarkt bieden of het perspectief bieden op werk met minder belastende arbeidsomstandigheden. Bovendien moet daarbij rekening worden gehouden met de kwalificaties waarover men reeds beschikt. Dit voorkomt dat onrealistische scholingstrajecten worden voorgesteld.

Het observatorium-karakter van het project wordt weerspiegeld door het grote aantal indicatoren dat de revue passeert. In het hoofdrapport Werkgelegenheid en scholing 1997 worden de meest opvallende factoren en ontwikkelingen in beeld gebracht. In de Statistische bijlage wordt in aanvulling daarop een totaaloverzicht gegeven van de in het hoofdrapport besproken indicatoren en eventuele alternatieve kengetallen, al dan niet op een ander aggregatieniveau, voor alle onderscheiden bedrijfssectoren, beroepen en opleidingen. Daarmee wordt beoogd de Statistische bijlage de functie te geven van een naslagwerk. De bijlage is daarom in tegenstelling tot het hoofdrapport niet geordend op basis van de risicofactoren die van invloed kunnen zijn op de scholingsbehoeften, maar op basis van de vier centrale invalshoeken: bedrijfsgrootte, bedrijfssector, beroep en opleiding. 
In dit werkdocument wordt een verantwoording van de gehanteerde onderzoeksmethoden gegeven. Het werkdocument is op dezelfde wijze opgebouwd als het vorige werkdocument Methodiek werkgelegenheid en scholing 1996, waarin verslag wordt gedaan van de onderzoeksmethodiek van de eerste overzichtsrapportage van het WSO. Deze opbouw is als volgt: Paragraaf 2 geeft aan welke databronnen in het WSO-project worden gebruikt, wat de onderzoekspopulatie van de betreffende bestanden is, hoe de steekproeftrekking heeft plaatsgevonden e.d. Vervolgens wordt in paragraaf 3 ingegaan op de gebruikte indicatoren. Daarbij komen telkens de definities, operationalisaties en berekeningswijzen aan de orde. Deze indicatoren worden in de meeste gevallen ook kwalitatief getypeerd op basis van een 5-puntsschaal, uiteenlopend van erg laag tot erg hoog. De wijze waarop dit is gebeurd wordt in paragraaf 4 besproken. Bovendien wordt in paragraaf 4 toegelicht hoe de trends zijn berekend en getypeerd. Daarna worden in paragraaf 5 de methodiek en de schattingsresultaten van de uitgevoerde analyses beschreven. In deze paragraaf wordt ingegaan op de methodiek ter bepaling van de samengestelde indicatoren van fysiek belastende arbeidsomstandigheden, technologische en organisatorische ontwikkelingen en de employability van de werkenden, de schattingen van de kans op arbeidsongeschiktheid en de methodiek die gehanteerd is bij het bepalen van perspectiefrijke scholingstrajecten. In de laatste paragraaf worden ten slotte enkele afrondende opmerkingen gemaakt.

\section{Databronnen}

Bij de invulling van het WSO is met name gebruik gemaakt van een zestal databronnen. Voor het in beeld brengen van de technologische en organisatorische ontwikkelingen betrof dit de Automatiseringsstatistieken, de Enquête Beroepsbevolking en het OSAArbeidsvraagsurvey. Voor het in beeld brengen van de verwachte arbeidsmarktontwikkelingen is met name gebruik gemaakt van arbeidsmarktprognoses zoals die zijn opgesteld in het Project Onderwijs-Arbeidsmarkt en de Enquête Beroepsbevolking. De laatstgenoemde databron is ook gebruikt bij het hoofdstuk over arbeidsomstandigheden. Voor de invulling van het hoofdstuk over scholingsinspanningen en employability heeft naast de Enquête Beroepsbevolking het OSA-Arbeidsaanbodsurvey een belangrijke rol gespeeld.

In het laatste hoofdstuk van het rapport, dat het bankwezen belicht, is gebruik gemaakt van het onderzoek Periodieke Opinie Peiling Identiteit en Arbeidsklimaat (POPIA) van de Rabobank-organisatie. Naast deze zes centrale databronnen is ook nog gebruik gemaakt van Kennis en economie 1996 (CBS, 1996a). Op deze laatste databron zal in dit werkdocument niet verder worden ingegaan.

\section{Automatiseringsstatistieken}

Jaarlijks wordt door het Centraal Bureau voor de Statistiek de publicatie Automatiseringsstatistieken uitgebracht (CBS, 1996a). In de publicatie van 1996 worden de 
resultaten weergegeven van het over het jaar 1994 gehouden onderzoek naar de administratieve automatisering bij ondernemingen en instellingen in de particuliere sector in Nederland. Het betreft onder andere de bestuurlijke automatisering, kantoorautomatisering, datacommunicatie, alsook andere, meer specifieke toepassingen, bijvoorbeeld in de onderwijssector, het transportwezen en het computergebruik bij het ontwerpen. De cijfers hebben betrekking op de automatiseringsgraad, automatiseringsapparatuur, automatiseringsbestedingen en automatiseringspersoneel.

Bij dit onderzoek wordt in principe uitgegaan van een populatie die bestaat uit alle ondernemingen en instellingen met vijf of meer medewerkers. Bij de computer-service- en IT-bureaus worden echter ook de bedrijven met minder dan vijf bedrijven geënquêteerd. In het WSO worden drie automatiseringsindicatoren gepresenteerd. Het gaat achtereenvolgens om de automatiseringsgraad, het -personeel en de -kosten.

\section{Project Onderwijs-Arbeidsmarkt (POA) 1997}

Het Project Onderwijs-Arbeidsmarkt (POA) is ontwikkeld door het Researchcentrum voor Onderwijs en Arbeidsmarkt (ROA, 1997a/b). Het bevat gegevens over de actuele en toekomstige positie van verschillende beroeps- en opleidingscategorieën op de arbeidsmarkt. ledere twee jaar worden middellange termijn prognoses opgesteld die betrekking hebben op de komende vijf jaar. De actuele informatie is in principe gebaseerd op gerealiseerde cijfers over het afgelopen jaar of het gemiddelde van de afgelopen twee jaren. Zo wordt een beeld gegeven van de absolute en relatieve omvang van het totaal aantal werkenden in een beroepsgroep en het aantal werkenden met een bepaalde opleidingsachtergrond. Bij de middellange-termijn-prognoses (tot het jaar 2002) wordt zowel voor beroepsgroepen als opleidingstypen het verwachte aantal baanopeningen aangegeven. Deze vraag naar nieuwkomers is uitgesplitst in de vraag als gevolg van nieuwe banen (uitbreidingsvraag) en de vervangingsvraag ${ }^{1}$. Voor de opleidingen wordt daarnaast ook de instroom van nieuwkomers op de arbeidsmarkt voorspeld, zodat vraag en aanbod aan elkaar kunnen worden gerelateerd. Op basis van deze confrontatie en de substitutieprocessen die hierdoor naar verwachting op gang zullen komen, wordt een indicator met betrekking tot de toekomstige arbeidsmarktperspectieven samengesteld.

Het Project Onderwijs-Arbeidsmarkt is niet gebaseerd op de verzameling van nieuwe data, maar maakt gebruik van bestaande informatiebronnen. De basisgegevens zijn voor een groot deel afkomstig van de Enquête Beroepsbevolking van het Centraal Bureau voor de Statistiek (zie aldaar) en de voorganger van deze enquête: de Arbeidskrachtentelling. Twee andere belangrijke informatiebronnen zijn de schoolverlatersenquêtes RUBS, de HBOmonitor en de WO-scanner. Als startpunt voor de voorspellingen gelden de werkgelegenheidsprognoses van het Centraal Planbureau (uitbreidingsvraag) en de

1. Zie voor de methodiek die ter grondslag ligt aan de verschillende arbeidsmarktprognoses. Borghans c.s., (1997). 
Referentieramingen van het Ministerie van Onderwijs, Cultuur en Wetenschappen (instroom nieuwkomers op de arbeidsmarkt).

\section{Enquête Beroepsbevolking (EBB)}

De Enquête Beroepsbevolking wordt uitgevoerd door het Centraal Bureau voor de Statistiek. De EBB is een steekproefonderzoek onder personen woonachtig in Nederland, met uitzondering van personen in inrichtingen, instellingen en tehuizen (institutionele bevolking). In de populatietotalen die voor de ophoging worden gebruikt, zijn de personen in inrichtingen, instellingen en tehuizen dan ook niet meegenomen (CBS, 1997).

De steekproef is een zogenaamde gestratificeerde steekproef. In de eerste trap worden gemeenten getrokken. Gemeenten met 7.300 of meer adressen zijn in alle maanden van het jaar in de steekproef vertegenwoordigd. De overige gemeenten zijn verdeeld over 65 strata die gevormd zijn op basis van 40 COROP-gebieden en 18 RBA gebieden. Vervolgens zijn hieruit gemeenten getrokken met kansen evenredig met het aantal adressen. Het aantal maanden dat deze gemeenten in de steekproef zijn opgenomen, is evenredig met het aantal adressen. In de tweede trap is een systematische steekproef van adressen getrokken in de gemeenten die getrokken zijn in de eerste stap. Indien een gemeente in de steekproef van een bepaalde maand valt, worden er tenminste twaalf adressen getrokken. In de gemeenten die meer dan één maand of het gehele jaar in de steekproef vallen, worden de adressen zodanig verdeeld dat telkens groepen van twaalf adressen (clusters) tot de steekproef van een bepaalde maand behoren. Die twaalf adressen uit een cluster komen uit eenzelfde omgeving met als gevolg dat de kenmerken van de bewoners van die adressen op elkaar lijken.

Als steekproefkader wordt het Geografisch Basisregister (GBR), een lijst van alle adressen in Nederland samengesteld door de PTT, gebruikt. Voor gebruikers van arbeidsmarktinformatie is het doorgaans wenselijk om de beroepen en opleidingen op een zo gedetailleerd mogelijk niveau in beeld te brengen. Deze detaillering kent echter haar grenzen in de beschikbaarheid van de EBB-gegevens. Voor de publicatie van EBBgegevens geldt een ondergrens voor de aantallen personen die in de tabellen gepubliceerd mogen worden. Voor jaarcijfers is dat minimaal 5.000 werkenden, voor meerjaarsgemiddelden is dat minimaal 2.500 werkenden.

In de EBB worden drie categorieën van gegevens verzameld: enquêtetechnische gegevens (adres e.d.), demografische gegevens (geslacht, geboortedatum e.d.) en gegevens ter beschrijving van personen naar hun positie op de arbeidsmarkt. Vragen over deze laatste categorie worden alleen gesteld aan personen van vijtien jaar of ouder. De vragen hebben onder andere betrekking op de maatschappelijke categorie waartoe men zich rekent, het al dan niet hebben van betaald werk, de positie in de werkkring, de arbeidsduur, het uitgeoefende beroep, het soort bedrijf, de gevolgde opleiding, de arbeidsmarktomstandigheden e.d. 
Het OSA-aanbodsurvey is een panel-survey. Deze enquête wordt uitgevoerd door de Organisatie voor Strategisch Arbeidsmarktonderzoek. Voor WSO is gebruik gemaakt van het Arbeidsaanbodsurvey van 1996 (Kunnen c.s., 1997). Het betreft de zevende golf van het OSA arbeidsaanbodpanel. De eerste golf van dit panel is in 1985 gehouden. De latere metingen zijn om de twee jaar gehouden (te weten 1986, 1988, 1990, 1992 en 1994 en 1996). In het Arbeidsaanbodsurvey worden gegevens verzameld omtrent de opleiding, de arbeidsmarktmobiliteit, de werksituatie en het inkomen van individuen die afkomstig zijn uit de potentiele beroepsbevolking van 16-65 jaar. Er wordt getracht om de deelnemers aan een vorige enquête weer mee te laten doen aan latere enquêtes. Het gedeelte van het panel dat niet meer deelneemt aan de enquêtes (non-respons, ouder dan 65 jaar) wordt opgevangen door nieuwe personen aan het bestand toe te voegen.

Het databestand heeft betrekking op in totaal 4.563 personen. In de analyses zijn alleen gegevens gebruikt van personen die in loondienst werkzaam zijn (geen zelfstandigen), 1665 jaar oud zijn en waarbij geen ontbrekende waarden voor de in analyses gebruikte variabelen voorkomen. Dit resulteert in een bestand bestaande uit 2.858 personen.

\section{Rabobank enquête POPIA}

Het POPIA (Periodieke Opinie Peiling Identiteit en Arbeidsklimaat)- onderzoek is een jaarlijks onderzoek uitgevoerd door Rabobank Nederland. Het betreft een onderzoek onder medewerkers van Rabobank Nederland en plaatselijke rabobanken waarin de opinie op verschillende terreinen wordt gepeild. Dit gebeurt met gebruikmaking van zogenaamde Likert-schalen, waarbij de antwoordcategorieën zijn: helemaal mee eens, mee eens, deels mee eens/deels niet mee eens, niet mee eens, helemaal niet mee eens. In hoofdstuk 8 van het WSO-rapport, waarin het bankwezen wordt uitgelicht is gebruik gemaakt van resultaten van het POPIA-onderzoek van 1994 tot en met 1997. In 1997 bevatte het bestand 1.098 personen. In de jaren daarvoor iets meer (1996: 1.100, 1995: 1.163, 1994: 1.212).

\section{Definities en indices}

In het WSO-rapport Werkgelegenheid en scholing 1997 en de bijbehorende Statistische bijlage komen een groot aantal begrippen en daaraan gerelateerde indicatoren aan de orde. De daaraan ten grondslag liggende definities worden in deze paragraaf in alfabetische volgorde op een rijtje gezet. Vervolgens komen nog enkele indices aan bod, die enige toelichting behoeven.

Gehanteerde definities

\section{Automatiseringsgraad}


Het percentage geautomatiseerde bedrijven. Er is sprake van een geautomatiseerd bedrijf zodra er over tenminste één computer wordt beschikt. (CBS, 1996a).

\section{Automatiseringskosten}

Kosten van hardware, software, inhuur personeel van derden, loonkosten eigen automatiseringspersoneel en overige kosten (CBS, 1996a).

\section{Atrofie}

Waardevermindering van menselijk kapitaal door het niet of onvoldoende gebruiken van kwalificaties.

\section{Bedrijfsspecifieke kwalificatieveroudering}

Waardevermindering van menselijk kapitaal door het verlaten van een organisatie waar kwalificaties zijn opgebouwd die uitsluitend in die organisatie waardevol zijn.

\section{Bijscholing}

Het uitbouwen van bestaande kennis of vaardigheden ten behoeve van de functie die een individu vervult.

\section{Brede inzetbaarheid}

De bereidheid van werkenden om, als dat nodig is, andere werkzaamheden te verrichten dan die tot het eigen functiegebied behoren.

\section{Employability}

Het in staat zijn en de wens hebben blijvend aantrekkelijk te zijn voor de arbeidsmarkt, door zowel te anticiperen als te reageren op veranderingen in arbeidstaken en werkomgeving (zie ook Thijssen, 1997).

\section{Ervaringsconcentratie}

Het steeds meer weten en kunnen op een steeds smaller vakgebied, met als gevolg een steeds minder gevarieerd ervaringenpakket en een steeds smallere inzetbaarheid, waardoor extra risico's optreden voor wat de arbeidsmarktpositie betreft (Thijssen, 1987).

\section{Externe opleiding of cursus}

Opleiding die buiten de directe werkomgeving wordt gegeven aan meerdere mensen tegelijk, die toegankelijk is voor mensen van verschillende arbeidsorganisaties en die plaatsvindt op een vooraf bepaalde plaats en tijd (CBS, 1995). 


\section{Functie-inhoudelijke kwalificatieveroudering}

Waardevermindering van menselijk kapitaal door veranderende kwalificatievereisten voor de functie die een individu vervult.

\section{Fysieke belasting}

Fysiek belastende arbeidsomstandigheden worden vastgesteld op basis van één of meer van de volgende belastingsfactoren: Krachtsinspanningen die tijdens het werk geleverd moeten worden, trillingen die als gevolg van het gebruik van gereedschap of apparaten tijdens het werk optreden, lawaaierige arbeidsomstandigheden en het werken in ploegendiensten.

\section{Herscholing}

Het opfrissen van kennis of vaardigheden die een individu reeds eerder heeft bezeten.

\section{Informatisering}

De mate waarin gewoonlijk of soms gebruik gemaakt wordt van een computer tijdens de werkzaamheden.

\section{Interne opleiding of cursus}

Opleiding die buiten de directe werkomgeving wordt gegeven aan meerdere mensen tegelijk van dezelfde arbeidsorganisatie en die plaatsvindt op een vooraf bepaalde plaats en tijd (CBS, 1995).

\section{Kwalificatieveroudering}

Waardevermindering van menselijk kapitaal.

\section{Kwalificatieveroudering door marktontwikkelingen}

Waardevermindering van menselijk kapitaal vanwege een afnemende of een zich verschuivende vraag naar arbeidskrachten met bepaalde beroepskwalificaties of een bepaalde opleidingsachtergrond.

\section{Mobiliteitsbereidheid en -vermogen}

Het vermogen en de wens van werknemers om zich van functie naar functie te verplaatsen.

\section{Omscholing}

Het verkrijgen van kennis of vaardigheden die vereist zijn voor het uitoefenen van een ander beroep of hetzelfde soort beroep in een andere bedrijfssector.

\section{Opleidingskosten}

Loonkosten van werknemers die in werktijd opleidingen volgden (gederfde arbeidskosten), de kosten van personeel betrokken bij het verzorgen of organiseren van opleidingen en de overige kosten zoals kosten betaald aan opleidingsinstanties, reis- en verblijfkosten en vergoedingen van studiekosten (CBS, 1995). 


\section{Overige opleidingsactiviteit}

Activiteit met een van te voren vastgesteld leerdoel, niet zijnde een interne of externe opleiding of een training op de werkplek. Tot deze activiteiten worden gerekend:

- het bezoeken van conferenties, workshops, lezingen of seminars;

- gepland leren via job rotation/functieroulatie of deelname aan kwaliteitscircels/georganiseerde groepsdiscussies;

- zelfstudie door middel van video/audit-tapes, schriftelijke cursussen, computerondersteunende methoden of gebruik van studiecentra (CBS, 1995).

\section{Psychische belasting}

Belasting als gevolg van het moeten verrichten van werkzaamheden onder een hoge tijdsdruk.

\section{Reallocatie}

Een verschuiving van de werkgelegenheid voor (1) binnen een bedrijfstak van het ene bedrijf naar het andere, of (2) de verschuiving van de werkgelegenheid binnen een beroepsgroep van de ene naar de andere bedrijfssector, of (3) de verschuiving van de werkgelegenheid voor een bepaald opleidingstype van het ene naar het andere beroep.

\section{Research \& Development (R\&D)}

omvat twee onderdelen:

\section{Research}

Creatieve systematische activiteiten gericht op het vermeerderen van de wetenschappelijke kennis en het wetenschappelijk inzicht (CBS, 1996b; gebaseerd op het Frascati-manual van de OESO).

\section{Development}

Creatieve systematische activiteiten, die er op gericht zijn de resultaten van het speurwerk te gebruiken om nieuwe of aanzienlijk verbeterde materialen of producten voort te brengen, alsmede nieuwe of aanzienlijk verbeterde toepassingsmogelijkheden, processen of systemen tot stand te brengen (CBS, 1996b; gebaseerd op het Frascati-manual van de OESO).

\section{Scholingsinspanning/scholingsparticipatie}

De intensiteit van scholing door bedrijven of instellingen. Deze scholing omvat interne en externe opleidingen, training op de werkplek en overige opleidingsactiviteiten, maar is exclusief trainingen in het kader van het leerlingwezen. 


\section{Slijtage}

Waardevermindering van menselijk kapitaal door het natuurlijk ouderwordingsproces, letsel of ziekte van werkenden.

\section{Training op de werkplek}

Opleiding van werknemers in de directe werkomgeving waarbij de normale werkuitrusting wordt gebruikt, waarbij de trainingsactiviteiten aan de volgende kenmerken voldoen:

- er is een nadrukkelijk leerdoel;

- er is door de bedrijfsleiding besloten dat de training nodig is;

- er heeft vooraf een bepaalde toekenning van tijd plaatsgevonden;

- er is een opleider bij betrokken (CBS, 1995).

\section{Indices}

Voor de constructie van figuur 5.1 in het hoofdrapport, waarin een beeld wordt geschetst van de ontwikkeling van de scholingsdeelname van werkenden in de periode 1985-1995, is gebruik gemaakt van het OSA-aanbodsurvey 1996. Hierbij is gebruik gemaakt van de antwoorden van respondenten met betrekking tot het aantal gevolgde cursussen. Daarbij is 1985 als basisjaar gekozen. De grafiek geeft dus de jaarlijkse groei van het aantal gevolgde cursussen weer waarbij 1985 steeds als vergelijkingsjaar is genomen. De gegevens over 1996 zijn niet toegevoegd omdat het OSA-bestand nog geen cijfers bevat over het volledige jaar 1996.

In figuur 5.1 en de tabellen 5.1 en 5.2 in het hoofdrapport wordt gebruik gemaakt van gegevens over cursusdeelname uit het OSA-Arbeidsaanbodsurvey. Het betreft hier alleen de werkenden in loondienst. Hierbij wordt gebruik gemaakt van de zes belangrijkste cursussen die men heeft gevolgd.

In paragraaf 6.3 van Werkgelegenheid en scholing 1997 is een aantal indices gepresenteerd die betrekking hebben op de zogenaamde niet-gerealiseerde bij- en omscholingsbehoefte. De idee achter deze indices is dat snelle technologische en organisatorische ontwikkelingen of een hoge psychische belasting vanwege de daarmee gepaard gaande kwalificatieveroudering leiden tot een behoefte aan bijscholing, die al dan niet ook feitelijk gerealiseerd wordt. Door respectievelijk de snelheid van de technologische en organisatorische ontwikkelingen en de mate van psychische belasting te relateren aan de hoogte van de gerealiseerde scholingsinspanningen en de employability van de werkenden, kan de niet-gerealiseerde bijscholingsbehoefte worden berekend. Bij de niet-gerealiseerde bijscholingsbehoefte wordt dus een technologie-indicator (TO) gerelateerd aan een bijscholingsindicator (S) of employability-indicator (E). De behoefte aan omscholing komt voort uit vanwege sterk fysiek belastende arbeidsomstandigheden of vanwege de werkgelegenheidskrimp en reallocatie. De combinatie van de werkgelegenheidskrimp en de reallocatie wordt de bruto baanvernietiging genoemd. Vandaar dat de niet-gerealiseerde omscholingsbehoefte wordt berekend door een baanvernietingingsindicator (D) of een 
indicator voor fysieke belasting $(F)$ te relateren aan een omscholingsindicator (S) of een indicator voor de employability van de werkenden $(E)$.

Tabel 3.1

Indices betreffende niet-gerealiseerde bij- en omscholingsbehoefte en tekortschietende employability

Indices

omschrijving

\section{Bedrijfssectoren (s)}

Niet gerealiseerde omscholingsbehoefte als gevolg van fysieke belasting $\left(\mathrm{OF}_{\mathrm{s}}\right)$

Niet gerealiseerde bijscholingsbehoefte als gevolg van psychische belasting $\left(\mathrm{BP}_{\mathrm{s}}\right)$

Niet-gerealiseerde bijscholingsbehoefte als gevolg van technologische en organisatorische ontwikkelingen $\left(\mathrm{BTO}_{\mathrm{s}}\right)$

Niet-gerealiseerde omscholingsbehoefte als gevolg van krimpende werkgelegenheid $\left(\mathrm{OK}_{\mathrm{s}}\right)$

Tekortschietende employability als gevolg van fysieke belasting $\left(\mathrm{EF}_{\mathrm{s}}\right)$

Tekortschietende employability als gevolg van psychische belasting $\left(\mathrm{EP}_{\mathrm{s}}\right)$

Tekortschietende employability als gevolg van technologische en organisatorische ontwikkelingen $\left(\mathrm{ETO}_{\mathrm{s}}\right)$

Tekortschietende employability als gevolg van krimpende werkgelegenheid $\left(\mathrm{EK}_{\mathrm{s}}\right)$

\section{Beroepssegmenten (b)}

Niet gerealiseerde omscholingsbehoefte t.o.v. als gevolg van fysieke belasting $\left(\mathrm{OF}_{\mathrm{b}}\right)$

Niet gerealiseerde bijscholingsbehoefte als gevolg van psychische belasting $\left(\mathrm{BP}_{\mathrm{b}}\right)$

Niet-gerealiseerde bijscholingsbehoefte als gevolg van informatisering $\left(\mathrm{BTO}_{\mathrm{b}}\right)$

Niet-gerealiseerde omscholingsbehoefte als gevolg van baanvernietiging $\left(\mathrm{OB}_{\mathrm{b}}\right)$
Indicator fysieke belasting $\left(\mathrm{F}_{\mathrm{s}}\right)$ t.o.v.

scholingsparticipatie in $1996\left(\mathrm{~S}_{\mathrm{s}}\right)$

Indicator psychische belasting $\left(\mathrm{P}_{\mathrm{s}}\right)$ t.o.v.

scholingsparticipatie in $1996\left(\mathrm{~S}_{\mathrm{s}}\right)$

Indicator technologische en organisatorische ontwikkelingen $\left(\mathrm{TO}_{\mathrm{s}}\right)$ t.o.v. scholingsparticipatie in $1996\left(S_{s}\right)$

Werkgelegenheidskrimp 1997-2002 $\left(K_{s}\right)$ t.o.v. scholingsparticipatie $1996\left(\mathrm{~S}_{\mathrm{s}}\right)$

Indicator fysieke belasting $\left(\mathrm{F}_{\mathrm{s}}\right)$ t.o.v.

employability-indicator in $1996\left(E_{s}\right)$

Indicator psychische belasting $\left(P_{s}\right)$ t.o.v.

employability-indicator in $1996\left(\mathrm{E}_{\mathrm{s}}\right)$

Indicator technologische en organisatorische ontwikkelingen $\left(\mathrm{TO}_{\mathrm{s}}\right)$ t.o.v. employability-indicator in $1996\left(E_{s}\right)$

Werkgelegenheidskrimp 1997-2002 $\left(\mathrm{K}_{\mathrm{s}}\right)$ t.o.v. employability-indicator $1996\left(E_{s}\right)$

Indicator fysieke belasting $\left(F_{b}\right)$ scholingsparticipatie in $1996\left(S_{b}\right)$

Indicator psychische belasting $\left(P_{b}\right)$ t.o.v.

scholingsparticipatie in $1996\left(\mathrm{~S}_{\mathrm{b}}\right)$

Informatisering $\left(\mathrm{TO}_{\mathrm{b}}\right)$ t.o.v. scholingsparticipatie 1996

$\left(\mathrm{S}_{\mathrm{b}}\right)$

Baanvernietiging 1997-2002 $\left(D_{b}\right)$ t.o.v. scholingsparticipatie $1996\left(\mathrm{~S}_{\mathrm{b}}\right)$

Tabel 3.1 (vervolg)

Indices betreffende niet-gerealiseerde bij- en omscholingsbehoefte 
Tekortschietende employability als gevolg van fysieke belasting $\left(\mathrm{EF}_{\mathrm{b}}\right)$

Tekortschietende employability als gevolg van psychische belasting $\left(\mathrm{EP}_{\mathrm{b}}\right)$

Tekortschietende employability als gevolg van informatisering $\left(\mathrm{ETO}_{\mathrm{b}}\right)$

Tekortschietende employability als gevolg van baanvernietiging $\left(\mathrm{EB}_{\mathrm{b}}\right)$

\section{Opleidingsrichtingen (o)}

Niet gerealiseerde omscholingsbehoefte als gevolg van fysieke belasting $\left(\mathrm{OF}_{\mathrm{o}}\right)$

Niet gerealiseerde bijscholingsbehoefte als gevolg van psychische belasting $\left(\mathrm{BP}_{0}\right)$

Niet-gerealiseerde bijscholingsbehoefte als gevolg van informatisering $\left(\mathrm{BTO}_{0}\right)$

Niet-gerealiseerde omscholingsbehoefte als gevolg van baanvernietiging $\left(\mathrm{OB}_{0}\right)$

Tekortschietende employability als gevolg van fysieke belasting $\left(\mathrm{EF}_{\mathrm{o}}\right)$

Tekortschietende employability als gevolg van psychische belasting $\left(E_{0}\right)$

Tekortschietende employability als gevolg van informatisering $\left(\mathrm{ETO}_{0}\right)$

Tekortschietende employability als gevolg van baanvernietiging $\left(E B_{\circ}\right)$
Indicator fysieke belasting $\left(\mathrm{F}_{\mathrm{b}}\right)$ t.o.v.

employability-indicator in $1996\left(E_{b}\right)$

Indicator psychische belasting $\left(\mathrm{P}_{\mathrm{b}}\right)$ t.o.v.

employability-indicator in $1996\left(\mathrm{E}_{\mathrm{b}}\right)$

Informatisering $\left(\mathrm{TO}_{\mathrm{b}}\right)$ t.o.v. employability-indicator in $1996\left(E_{b}\right)$

Baanvernietiging 1997-2002 $\left(D_{b}\right)$ t.o.v. employabilityindicator in $1996\left(E_{b}\right)$

Indicator fysieke belasting $\left(\mathrm{F}_{0}\right)$ t.o.v.

scholingsparticipatie in $1996\left(\mathrm{~S}_{0}\right)$

Indicator psychische belasting $\left(\mathrm{P}_{\mathrm{o}}\right)$ t.o.v.

scholingsparticipatie in $1996\left(\mathrm{~S}_{0}\right)$

Informatisering $\left(\mathrm{TO}_{\circ}\right)$ t.o.v. scholingsparticipatie 1996 $\left(\mathrm{S}_{0}\right)$

Baanvernietiging 1997-2002 $\left(D_{0}\right)$ t.o.v. scholingsparticipatie $1996\left(\mathrm{~S}_{0}\right)$

Indicator fysieke belasting $\left(F_{0}\right)$ t.o.v. employability-indicator in $1996\left(E_{0}\right)$

Indicator psychische belasting $\left(P_{0}\right)$ t.o.v. employability-indicator in $1996\left(E_{0}\right)$

Informatisering $\left(\mathrm{TO}_{\mathrm{o}}\right)$ t.o.v. employability-indicator in $1996\left(E_{0}\right)$

Baanvernietiging 1997-2002 ( $\left.D_{0}\right)$ t.o.v. employabilityindicator in $1996\left(\mathrm{E}_{0}\right)$

Aangezien in de gebruikte data met betrekking tot de scholingsinspanning (Enquête Beroepsbevolking) geen onderscheid kon worden gemaakt tussen bijscholing en omscholing, is bij het indiceren van zowel de bij- als omscholingsbehoefte uitgegaan van de totale feitelijke scholingsparticipatie. Dit is gebeurd voor zowel bedrijfssectoren, beroepssegmenten en opleidingsrichtingen (zie tabel 3.1).

De zes indices zijn als volgt berekend. Allereerst zijn alle indicatoren $\left(F_{s}, P_{s}, T O_{s}, K_{s}, F_{b}, P_{b}\right.$, $T O_{b}, D_{b}, F_{o}, P_{o}, T O_{o}, D_{o}$, getransformeerd tot $Z$-scores. Hierbij geldt:

$$
Z_{i}=\frac{\mu-X_{i}}{\sigma}
$$


waarbij $\sigma$ de standaarddeviatie is, $\mu$ het gemiddelde en $X_{i}$ de indicator $X$ op aggregatieniveau $i$. In principe zijn daarna de relevante $Z$-scores op elkaar gedeeld. Om echter te voorkomen dat door 0 wordt gedeeld zijn eerst zes hulpvariabelen $\left(H_{i}\right)$ gecreëerd:

$$
H_{i}=\frac{Z(F)+100}{Z(R)+100}
$$

waarbij $Z(F)$ de Z-score van een belastings-, technologie- of krimp/baanvernietigingsindicator is en $Z(R)$ de Z-score van de scholings- of employability-indicator.

Vervolgens zijn de hulpvariabelen getransformeerd tot Z-scores. Zoals alle Z-scores hebben deze indices het gemiddelde 0 en de standaarddeviatie 1.

\section{Typeringen en trends}

In deze vierde paragraaf wordt achtereenvolgens ingegaan op de wijze van typeren van de gebruikte indicatoren en de berekeningswijze bij het vaststellen van de trends.

\section{Typeringen}

In Werkgelegenheid en scholing 1997 worden indicatoren per bedrijfsgrootte, per bedrijfssector, per beroep en per opleiding gepresenteerd. Deze indicatoren zijn ook allemaal kwalitatief getypeerd. Daarbij is meestal gekozen voor een relatieve typering volgens de symmetrische methode (Wieling c.s., 1990). Bij een relatieve typering geldt dat de classificatie van de variabele voor een bepaalde aggregatieniveau (bijvoorbeeld beroepen) afhankelijk wordt gemaakt van de overige waarden van de desbetreffende variabele. Bij de symmetrische methode wordt de grenzenindeling zodanig vastgesteld dat de verschillende waarden worden verdeeld over de vijf onderscheiden typeringen. Daarbij wordt gebruik gemaakt van het gemiddelde $(\mu)$ en de standaarddeviatie $(\sigma)$ van de te kwalificeren gegevens.

Daarbij wordt de volgende symmetrische grenzenindeling gehanteerd:

$\begin{array}{llll} & X \leq \mu-1,282 \sigma & \text { (relatief) erg laag/erg klein } & 10 \% \text { kans } \\ \mu-1,282 \sigma< & X \leq \mu-0,524 \sigma & \text { (relatief) laag/klein } & 20 \% \text { kans } \\ \mu-0,524 \sigma< & X \leq \mu+0,524 \sigma & \text { gemiddeld } & 40 \% \text { kans } \\ \mu+0,524 \sigma< & X \leq \mu+1,282 \sigma & \text { (relatief) hoog/groot } & 20 \% \text { kans } \\ \mu+1,282 \sigma< & X & \text { (relatief) erg hoog/erg groot } & 10 \% \text { kans }\end{array}$


Bij enkele indices uit hoofdstuk 6 is de indicator $X$ een $Z$-score met $\mu=0$ en $\sigma=1$. Daarvoor is de kwalitatieve typering volgens dezelfde regels toegekend.

Bij niet normaal verdeelde grootheden is ook gebruik gemaakt van de kwantielenmethode om de waarden van typeringen te kunnen voorzien. Daarbij worden de te typeren gegevens van laag naar hoog gerangschikt en krijgen ze een typering op basis van hun positie in de rangschikking. Dit is bijvoorbeeld het geval bij de typering van de mate waarin werkenden te kampen hebben met belastende arbeidsomstandigheden.

\section{Trends}

Voor een aantal indicatoren zijn op basis van de jaarlijks uitgebrachte statistieken trends berekend. De wijze waarop deze trends zijn vastgesteld is gelijk aan de methodiek die gehanteerd is in De arbeidsmarkt naar opleiding en beroep tot 2002 (zie Borghans c.s., 1997). Uitgangspunt is een exponentieel model dat wordt geschat en waarin de ontwikkeling van $x_{t}$ wordt verklaard uit een constante term $\alpha$ en een trendvariabele $t$, $\mathrm{t}=1, \ldots \mathrm{n}$ :

$$
\ln \left(x_{t}\right)=\alpha+\beta t
$$

De OLS-schatting voor $\beta$ vormt de trend-indicator. Omdat de natuurlijke logaritme van de te verklaren variabele is opgenomen in de vergelijking, kan deze indicator worden geïnterpreteerd als de jaarlijkse procentuele groei. Een trendberekening op basis van een vijfjarige tijdreeks is het meest geschikt. Bij enkele indicatoren was echter geen vijfjarige tijdreeks beschikbaar en is gebruik gemaakt van een driejarige tijdreeks.

De OLS-schatter voor $\beta$ is voor een reeks van vijf jaren gelijk aan:

$$
\hat{\beta}=-0.2 \ln \left(x_{1}\right)-0.1 \ln \left(x_{2}\right)+0.1 \ln \left(x_{4}\right)+0.2 \ln \left(x_{5}\right)
$$

Voor de driejarige trend is dit:

$$
\hat{\beta}=-0.5 \ln \left(x_{1}\right)+0.5 \ln \left(x_{3}\right)
$$

Naast de trend zelf is ook de variantie van de geschatte trend berekend. Bij een vijfjarige trend is dit:

$$
\hat{\sigma}_{\beta}^{2}=\frac{1}{30} \sum_{t=1}^{t=5} \ln ^{2} x_{t}-\frac{1}{150}\left(\sum_{t=1}^{t=5} \ln x_{t}\right)^{2}-\frac{1}{3} \beta^{2}
$$


En bij een driejarige trend:

$$
\hat{\sigma}_{\beta}^{2}=\frac{1}{2} \sum_{t=1}^{t=3} \ln ^{2} x_{t}-\frac{1}{6}\left(\sum_{t=1}^{t=3} \ln x_{t}\right)^{2}-\beta^{2}
$$

De variantie is berekend omdat tijdreeksen met een vrij grillig verloop per toeval een zeer sterke trendwaarde kunnen opleveren. Als de standaarddeviatie van de trend groter is dan de trend zelf wordt in het Informatiesysteem Onderwijs-Arbeidsmarkt de trend niet meer gepresenteerd. In het WSO-onderzoek wordt de trend in dat geval 'fluctuerend' genoemd, namelijk wanneer:

$$
\left|\frac{\hat{\beta}}{\hat{o}_{\beta}}\right|<1
$$

In de overige gevallen is de trend als volgt kwalitatief getypeerd:

$\begin{array}{rlrll} & \text { trend } \leq & -0,10 & \text { sterk dalend } \\ -0,10< & \text { trend } \leq & -0,03 & \text { dalend } \\ -0,03< & \text { trend } \leq & 0,03 & \text { constant } \\ 0,03<\text { trend } & \leq 0,10 & \text { stijgend } \\ 0,10<\text { trend } & & & \text { sterk stijgend }\end{array}$

\section{Analyses}

In het rapport Werkgelegenheid en scholing 1997 is verslag gedaan van de resultaten van enkele statistische analyses. De gehanteerde methodiek en de schattingsresultaten zijn omwille van de leesbaarheid in het rapport achterwege gelaten. Deze komen in dit werkdocument aan de orde. Achtereenvolgens wordt ingegaan op de methode die gebruikt is voor het meten van fysieke belasting (paragraaf 5.1), de schattingen van de kans op arbeidsongeschiktheid (paragraaf 5.2), de samengestelde indicator voor technologische en organisatorische ontwikkelingen per bedrijfssector (paragraaf 5.3), de employability van de werkenden (5.4) en de perspectiefrijke scholingstrajecten (paragraaf 5.5).

\subsection{Fysieke belasting}

In figuur 2.1 van Werkgelegenheid en scholing 1997 is een samengestelde indicator van de fysieke belasting van de werkenden per bedrijfssector gepresenteerd. Een soortgelijke indicator is ook in hoofdstuk 6 gebruikt bij de risicoprofielen voor beroepssegmenten en opleidingsrichtingen. Voor zowel bedrijfssectoren, beroepssegmenten als opleidingsrichtingen is de fysieke belasting bepaald als een combinatie van de drie belastingsfactoren 
kracht, lawaai en trilling. Daartoe is een principale-componenten-analyse uitgevoerd. De factorladingen voor de belastingsfactoren worden weergegeven in tabel 5.1.

Tabel 5.1

De factorladingen per belastingsfactor

\begin{tabular}{lccc} 
Belastingsfactoren & bedrijfssector & $\begin{array}{l}\text { factorlading } \\
\text { beroepssegment }\end{array}$ & opleidingsrichting \\
\hline Kracht & 0,86 & 0,78 & 0,93 \\
Lawaai & 0,86 & 0,81 & 0,95 \\
Trilling & 0,93 & 0,88 & 0,96 \\
\hline
\end{tabular}

Bron: ROA/CBS

Vervolgens kan per bedrijfssector, beroep, en opleiding een factor-score $\left(F_{k}\right)$ worden berekend als lineaire combinatie van de originele variabelen (i) voor het betreffende arbeidsmarktsegment k:

$$
F_{k}=\sum_{i=1}^{p} W_{i} X_{i k}
$$

waarbij $X_{i k}$ de gestandaardiseerde waarde van de scholingsindicator $i$ is in arbeidsmarktsegment $k$ en $W_{i}$ de factorlading voor scholingsindicator i (Norusis, 1990). De factorscore is een indicatie voor de hoogte van de variabele 'fysieke belasting'. Deze indicator is vervolgens omgeschaald zodat de maximale waarde 100 wordt. Deze omschaling vergemakkelijkt de vergelijking tussen de fysieke en psychische belasting per bedrijfssector, beroep en opleiding.

\subsection{De kans op arbeidsongeschiktheid}

In paragraaf 2.4 van het WSO-rapport wordt gekeken naar het effect van belastende arbeidsomstandigheden op de verschillen in het risico op arbeidsongeschiktheid tussen de diverse opleidingscategorieën. Als te verklaren variabele is genomen het aandeel van arbeidsongeschikte werknemers per opleidingstype. De verklarende variabelen zijn de belastingsfactoren kracht, lawaai, trilling en tijdsdruk. Daarnaast zijn het percentage $40+$ 'ers, het percentage vrouwen en het opleidingsniveau als controle-variabelen in de analyse opgenomen. Tabel 5.2 geeft een overzicht van de schattingsresultaten. Opmerkelijk is dat - in tegenstelling tot de variabelen die betrekking hebben op de fysieke belasting van de werkenden - de tijdsdruk-variabele waarmee de psychische belasting wordt geïndiceerd, geen significant effect heeft op de kans op arbeidsongeschiktheid. Dit is voor een belangrijk deel toe te schrijven aan het feit dat bij vrijwel alle opleidingsrichtingen een hoog percentage van de werkenden aangeeft onder tijdsdruk te moeten werken.

Tabel 5.2 
OLS-schatting van de kans op arbeidsongeschiktheid naar opleidingstype in 1996

\begin{tabular}{lcc}
\hline Variabele & parameter & t-waarde \\
\hline Constante & 1,39 & 1,56 \\
Kracht & 0,01 & 1,64 \\
Lawaai & 0,02 & 2,06 \\
Trilling & 0,02 & 1,70 \\
Tijdsdruk & 0,01 & 0,90 \\
Percentage 40+'ers & 0,03 & 4,98 \\
Percentage vrouw & $-0,00$ & $-1,58$ \\
Opleidingsniveau & $-0,71$ & $-4,66$ \\
& & \\
Aantal cases: & 113 & \\
R-kwadraat: & 0,712 & \\
R-kwadraat: & 0,692 & \\
& & \\
\hline
\end{tabular}

\subsection{Technologische en organisatorische ontwikkelingen per bedrijfssector en -grootte}

In hoofdstuk 3 wordt voor de diverse bedrijfssectoren, beroepsgroepen en opleidingstypen aangegeven in hoeverre de werkenden te kampen hebben met snelle technologische en organisatorische ontwikkelingen. Bij de beroepen en opleidingen is daarbij gebruik gemaakt van de mate waarin de verschillende categorieën werkenden geconfronteerd worden met een informatisering van de werkzaamheden. Bij de indicatoren naar bedrijfssector en bedrijfsgrootte zijn zowel de technologische als organisatorische ontwikkelingen in beeld gebracht. De afzonderlijke indicatoren naar bedrijfsgrootte en bedrijfssector zijn respectievelijk te vinden in de delen 1 en 2 van de Statistische bijlage. In de tabellen 3.1 en 3.2 van het rapport wordt een samengestelde indicator gepresenteerd. Deze indicator is met behulp van een principale-componenten-analyse berekend. De variabelen die gereduceerd worden tot één overkoepelende indicator voor technologische en organisatorische ontwikkelingen zijn:

- het percentage bedrijven met R\&D in 1994;

- de gemiddelde omvang van R\&D in 1994;

- het percentage R\&D voor vernieuwing van producten of diensten in 1994;

- het percentage $R \& D$ voor vernieuwing van productieprocessen in 1994;

- het percentage producten/diensten dat in 1992-1994 ingrijpend is gewijzigd;

- het percentage producten/diensten dat in 1992-1994 op enkele aspecten is gewijzigd;

- het percentage bedrijven waarbij de positie van het bedrijf in 1992-1994 is veranderd en

- het percentage bedrijven met interne organisaties in 1992-1994.

De factorladingen voor deze variabelen worden weergegeven in tabel 5.3.

Tabel 5.3

De factorladingen per technologie- en organisatie-variabele 
Percentage bedrijven met R\&D

Gemiddelde omvang R\&D

Percentage R\&D t.b.v. vernieuwing producten/diensten

Percentage R\&D t.b.v. vernieuwing productieprocessen

Percentage producten/diensten dat ingrijpend is gewijzigd

Percentage producten/diensten dat op enkele aspecten is gewijzigd

Percentage bedrijven waarbij de positie van het bedrijf is veranderd

Percentage bedrijven met interne organisaties
0,41

0,20

0,94

0,17

0,92

0,77

0,07

0,65
0,95

0,76

0,99

0,98

0,98

0,83

0,92

0,92

Bron: OSA/ROA

\subsection{Employability van de werkenden}

Voor het bepalen van de employability van de werkenden in hoofdstuk 5 is een drietal indicatoren gebruikt, te weten (1) de mobiliteitsbereidheid en het mobiliteitsvermogen, (2) het risico op ervaringsconcentratie en (3) de mate waarin de werkenden breed inzetbaar zijn. Een geringe mobiliteitsbereidheid en het niet breed inzetbaar zijn heeft een negatief effect op de employability. Ervaringsconcentratie leidt eveneens tot een geringere employability. Met behulp van een principale-componenten-analyse is getracht deze drie indicatoren terug te brengen tot één employability-indicator. Deze employability indicator is gebruikt in figuur 5.4 .

De scores op de drie indicatoren zijn gegenereerd uit het OSA-aanbodsurvey 1996. Brede inzetbaarheid is daarbij bepaald aan de hand van de vraag of een werknemer, indien de werkgever hem of haar daarom vraagt, inzetbaar is voor werkzaamheden die eigenlijk tot een ander functiegebied behoren. De mobiliteitsbereidheid is bepaald aan de hand van de vraag of men de afgelopen 12 maanden actief gezocht heeft naar een andere baan. Bij de bepaling van het risico op ervaringsconcentratie is uitgegaan van de verblijfstijd van een werknemer in dezelfde functie bij dezelfde werkgever. Daarbij is als maatstaf voor een verhoogd risico op ervaringsconcentratie uitgegaan van een verblijfsduur van langer dan 10 jaar in de huidige functie.

Tabel 5.4 toont de afzonderlijke factorladingen van de drie indicatoren. Deze factorladingen laten zien dat brede inzetbaarheid, mobiliteitsbereidheid en ervaringsconcentratie goede indicatoren zijn voor employability. De mobiliteitsbereidheid blijkt wat betreft verklaringskracht het kleinst te zijn.

Tabel 5.4

De factorladingen per employability indicator (naar opleidingsrichting) 
Met deze factorladingen kan vervolgens de employability indicator worden geconstrueerd, die ten grondslag ligt aan figuur 5.4.

\subsection{Perspectiefrijke scholingstrajecten}

In hoofdstuk 7 van het rapport Werkgelegenheid en scholing 1997 zijn de scholingstrajecten in kaart gebracht die aan de getraceerde potentiële doelgroepen de beste perspectieven bieden op behoud van werk. Deze doelgroepen zijn in hoofdstuk 6 van dat rapport in beeld gebracht.

Bij de bepaling van perspectiefrijke scholingstrajecten hebben drie criteria een rol gespeeld: de verwachte arbeidsmarktontwikkelingen tot 2002, de mate van verwantschap tussen de huidige kwalificaties en de kwalificaties van de uitwijkmogelijkheden en de mate waarin er in de uitwijkberoepen sprake is van minder fysiek belastende arbeidsomstandigheden dan in het huidige beroep.

\section{Arbeidsmarktperspectieven}

De arbeidsmarktperspectieven naar opleiding en beroep zijn bepaald op basis van de arbeidsmarktprognoses voor de periode 1997-2002, zoals die zijn opgesteld in het kader van het Project Onderwijs-Arbeidsmarkt (ROA 1997a/b, Borghans, c.s. 1997). Voor de verschillende opleidingstypen zijn de verwachte vraag en het verwachte aanbod aan elkaar gerelateerd. Als aanbod is de som genomen van de verwachte arbeidsmarktinstroom van nieuwkomers op de arbeidsmarkt in de periode 1997-2002 en het aantal werklozen aan het begin van de prognoseperiode (i.c. 1997) dat korter dan 1 jaar werkloos is. De verwachte vraag bestaat uit de som van uitbreidings-, vervangings- en (passieve) substitutievraag. De Indicator Toekomstige Arbeidsmarktperspectieven (ITA) wordt als volgt bepaald:

ITA = $100+\%$ instroom + \% kortdurig werklozen in 1997 substitutievraag)

$(100+\max [0, \%$ uitbreidingsvraag $]+\%$ vervangingsvraag $+\%$

Bij een ITA $<1$ kan er worden gesproken over een goed arbeidsmarktperspectief voor het desbetreffende opleidingstype. Bij de bepaling van het arbeidsmarktperspectief voor beroepen is het niet mogelijk om het aanbod te confronteren aan de vraag. Daarom wordt bij de beroepen gekeken naar het werkgelegenheidsperspectief, d.w.z. de verwachte baanopeningen in de periode 1997-2002. De verwachte baanopeningen worden als erg hoog getypeerd wanneer het aantal baanopeningen minimaal $32 \%$ is van het aantal werkenden aan het begin van de prognoseperiode. 
Het tweede criterium voor de bepaling van perspectiefrijke scholingstrajecten voor beroepof opleidingscategorieën die met risico's op verlies van werk worden bedreigd, is de mate van verwantschap tussen de huidige en de beoogde kwalificaties. Bij een grote mate van verwantschap kunnen de omscholingskosten, zowel uit financieel als mentaal oogpunt, zo laag mogelijk worden gehouden en zal men zo snel mogelijk weer aan de slag kunnen komen. De mate van verwantschap tussen beroepen is bepaald op basis van de opleidingsachtergrond van de werkenden in ieder beroep. De mate van verwantschap tussen opleidingen is bepaald op basis van het beroependomein van de verschillende opleidingstypen. Als aanvullende voorwaarde is gesteld dat het uitwijkberoep maximaal één functieniveau hoger mag liggen dan het huidige beroep en dat de perspectiefrijke omscholing maximaal één opleidingsniveau hoger mag liggen dan de huidige opleidingsachtergrond.

Het beroependomein van een opleiding is het uitgangspunt bij de ontwikkeling van een maatstaf voor verwantschap in kwalificaties. Borghans (1992) en Koeslag en Van der Velden (1996) laten zien dat de kans dat een werknemer van opleiding i en een werknemer

van opleiding j werkzaam zijn in hetzelfde beroep gedefinieerd kan worden als:

$$
K(i, j)=\sum_{b} P_{i}^{b} P_{j}^{b}
$$

waarbij:

$P_{i}^{b}=$ de proportie van werknemers uit opleiding i die een baan hebben gevonden in beroep b, en

$P_{j}^{b}=$ de proportie van werknemers uit opleiding $\mathrm{j}$ die een baan hebben gevonden in beroep b.

De mate van verwantschap tussen twee opleidingen (opleiding i en j) kan vervolgens gedefinieerd worden als de mate waarin de opleidingen eenzelfde beroependomein hebben. De kans dat de opleidingen eenzelfde beroependomein hebben - de similarity-index SIM (i,j) wordt bepaald door de kans dat de werknemers van opleiding $i$ in een beroep werknemers van opleiding $\mathrm{j}$ treffen $\mathrm{K}(\mathrm{i}, \mathrm{j})$, waarbij een correctie plaatsvindt voor de spreiding van $\mathrm{i}$ en $\mathrm{j}$ over de beroepen (de termen $\mathrm{K}(\mathrm{i}, \mathrm{i})$ en $\mathrm{K}(\mathrm{j}, \mathrm{j})$ in de noemer):

$$
\operatorname{SIM}(i, j)=\frac{K(i, j)}{\sqrt{K(i, i) K(j, j)}}
$$


De similarity-index is 1 , wanneer de twee opleidingen een identiek beroependomein hebben. Dit betekent dat de werknemers van opleiding i, met gelijke proporties in dezelfde beroepen werkzaam zijn als de werknemers van opleiding j. De maatstaf is nul wanneer de werknemers van beide opleidingen elkaar in geen enkel beroep op de arbeidsmarkt treffen. Als criterium voor een grote verwantschap tussen twee opleidingen gold $\operatorname{SIM}(\mathrm{i}, \mathrm{j}) \geq 0,5$.

De verwantschap tussen beroepen is op parallelle wijze bepaald op basis van de opleidingsachtergrond van de werkenden in de verschillende beroepen. Als criterium voor een grote verwantschap tussen twee beroepen gold eveneens dat de similarity-index groter of gelijk is aan 0,5 .

\section{Minder fysiek belastende arbeidsomstandigheden}

Wanneer er voor een beroepen of opleidingen, waarin fysiek belastende arbeidsomstandigheden veelvuldig voorkomen, segmenten genoemd worden die verwant zijn met het huidige beroep of opleiding, dan moeten de uitwijkberoepen en -opleidingen om een goed alternatief te kunnen zijn voor werkenden die met verlies van werk bedreigd worden vanwege deze belastende arbeidsomstandigheden, vanzelfsprekend ook gekenmerkt worden door minder belastende arbeidsomstandigheden. De beroepen en opleidingen worden daarom voor deze risico-groepen alleen een perspectiefrijk alternatief genoemd wanneer ze tenminste op één belastingfactor beter scoren en op geen enkele belastingsfactor slechter scoren dan in het huidige beroep of de huidige opleiding.

\section{Besluit}

Werkgelegenheid en scholing 1997 en de bijbehorende Statistische bijlage vormen te zamen de tweede overzichtsrapportage van het Werkgelegenheid en Scholing Observatorium (WSO). In deze beide publicaties is getracht de resultaten van het verrichte onderzoek op een toegankelijke wijze te presenteren. In aanvulling daarop is in dit werkdocument de gehanteerde methodiek toegelicht.

In dit werkdocument is aangegeven welke databronnen in het WSO-project zijn gebruikt. Daarbij is telkens een korte beschrijving van de verschillende databronnen gegeven. Bovendien zijn alle gebruikte indicatoren, definities, operationalisaties en berekeningswijzen aan de orde gekomen. Daarnaast is aangegeven op welke wijze de indicatoren kwalitatief zijn getypeerd en hoe de trends zijn berekend. Vervolgens is nader ingegaan op enkele specifieke analyses, namelijk de bepaling van de employability van de werkenden en de technologische en organisatorische vernieuwingen in de bedrijfssectoren (in casu een principale-componenten-analyse), de kans op arbeidsongeschiktheid en de bepaling van de perspectiefrijke scholingstrajecten. 
In 1998 zal het WSO verder worden ontwikkeld. Hiervan zal verslag worden gedaan in enkele afzonderlijke thema-rapporten. De in dat kader te verrichten onderzoeksactiviteiten zullen hun weerslag vinden in het derde WSO-rapport Werkgelegenheid en scholing 1999, waarin een actualisering zal plaatsvinden van de in Werkgelegenheid en scholing 1997 gepresenteerde informatie.

\section{Literatuur}

Borghans, L. (1992), A Histo-Topographic Map of Dutch University Studies, ROA-W1992/5E, Maastricht.

Borghans, L. en H. Heijke (1993), Forecasting the Educational Structure of Occupations: A Manpower Requirement Approach with Substitution, ROA-RM-1993/2E, Maastricht.

Borghans, L. en H. Heijke (1994), Het voorspellen van de beroepenstructuur van bedrijfstakken binnen het kader van het Athena-model, ROA-W-1994/1, Maastricht.

Borghans, L., A. de Grip, J. Delmee, A. Matheeuwsen, W. Smits, J. van Loo, (1997), Methodiek arbeidsmarktprognoses en -indicatoren 1997-2002, ROA-W-1997/6, Maastricht.

Broersma, L. en P.A. Gautier (1995), Vernietiging en creatie van banen in de industrie, E $S$

2 augustus 1995, pp. 685-689.

CBS (1995), Bedrijfsopleidingen 1993, Particuliere Sector, Centraal Bureau voor de Statistiek, Voorburg/Heerlen.

CBS, (1996a), Automatiseringsstatistieken, Particuliere sector 1994-1996 en Industriële automatisering (CAD/CAM) 1994-1996, Centraal Bureau voor de Statistiek, Voorburg/Heerlen.

CBS (1996b), Kennis en economie 1996, Centraal Bureau voor de Statistiek, Voorburg/Heerlen.

CBS, (1997), Enquête Beroepsbevolking 1996, Centraal Bureau voor de Statistiek, Voor burg/Heerlen.

Greene, W.H. (1993), Econometric Analysis, Prentice Hall, New Jersey.

Grip, A de, M. van Smoorenburg, L. Borghans, N. Jonker, (1997), Methodiek werkgelegenheid en scholing 1996, Maastricht, ROA-W-1997/1.

Koeslag, M. en R.K.W. van der Velden (1996), De afbakening van beroependomeinen van opleidingen in het middelbaar beroepsonderwijs, ROA-R-1996/10, Maastricht.

Kunnen, R., W.C.M. Praat en H.R.M. Smulders (1997), Trendrapport Aanbod van arbeid 1997, Organisatie voor Strategisch Arbeidsmarktonderzoek (OSA), Den Haag. 
Norusis, M.J., (1990), SPSS Introductory Statistics Student Guide, SPSS Inc. Chicago.

ROA (1997a), De arbeidsmarkt naar opleiding en beroep tot 2002, Researchcentrum voor Onderwijs en Arbeidsmarkt, ROA-R-1997/7.

ROA (1997b), De arbeidsmarkt naar opleiding en beroep tot 2002. Statistische bijlage, Researchcentrum voor Onderwijs en Arbeidsmarkt, ROA-R-1997/7B.

ROA, (1998), Werkgelegenheid en scholing 1997, Researchcentrum voor Onderwijs en Arbeidsmarkt, Universiteit Maastricht.

ROA (1998), Werkgelegenheid en scholing 1997, Statistische bijlage, Researchcentrum voor Onderwijs en Arbeidsmarkt, Universiteit Maastricht.

Thijssen, J.G.L. (1987), Het leven van de verouderde werknemer in veranderende organisaties, Paper Congres Onderzoeks-Thema-Groep Onderwijsleerprocessen, Katholieke Universiteit Nijmegen, Nijmegen.

Thijssen, J.G.L. (1997), Employability en employment: terminologie, modelvorming en opleidingspraktijk, Opleiding en Ontwikkeling, nr. 10, pp 9-14.

Wieling, M.H., A. de Grip \& E.J.T.A. Willems (1990), Een systematische kwalitatieve typering van arbeidsmarktinformatie, ROA-W-1990/8, Researchcentrum voor Onderwijs en Arbeidsmarkt, Universiteit Maastricht. 